\title{
A Study On Warm Mix Asphalt Technology On Bituminous Mixesusing Rediset-Wmx
}

\author{
AmirhamzaM. Chariwala ${ }^{1}$, Shivam S. Patel ${ }^{2}$, Mursalin M. Shaikh ${ }^{3}$, \\ Sagar A. Tailor ${ }^{4}$ \\ 1,2,3,4 (Department of Civil Engineering, Gujarat Technological University - Chandkheda, Gujarat, India)
}

\begin{abstract}
All around the world efforts are made and being forward to protect the environment. At present the main emphasis is on reducing $\mathrm{CO}_{2}$ emissions in the view of reducing the greenhouse gases and effect. Nowadays the construction of roads can be done by using the hot mix asphalt (HMA) technique which consists of aggregates and bitumen mixed at the higher temperature approximately $150^{\circ}$ to $170^{\circ} \mathrm{C}$. The main concern with this HMA technology is, it requires great amount of energy for the production of bituminous mixes and also emits the massive amount of greenhouse gases in to the environment.Warm mix asphalt (WMA) is the recent technology and one of the solutions used to reduce the mixing temperature of bituminous concrete without affecting the quality of pavement and act as the alternative of the HMA technology. WMA technology reduces the mixing temperature about $20^{\circ}$ to $40^{\circ} \mathrm{C}$. In this study, warm mix design of bituminous concrete for surface course is carried out by using the WMX additive with the bitumen of viscosity grade-30 (VG-30). The optimum binder content to produce the bituminous mix using the WMX additive will be achieved by the marshall test. Then after optimum dosage of WMX additive and favourable temperature for WMX additive at which it can perform successfully. Qualified study can be done to know the stability of WMX additive with binder. Laboratory testing is also carried out to find the physical properties of aggregate and bitumen of VG-30 grade tests with or without the WMX additive.
\end{abstract}

Keywords -Hot mix asphalt, Warm mix asphalt, Optimum Binder content, Optimum Temperature, Optimum Dose

\section{Introduction}

The area of work of this study covers laboratory study on bitumen, bituminous mixes and bituminous mixes with additive. The purpose of this study is mainly concentrated to find out the optimum temperature by which the bituminous concrete mixing temperature is reduced through the warm mix asphalt technology. The asphalt industry is the great concern existing in the world related to the atmosphere emissions for the greenhouse effect and the energy consumption. The current industrial tendency is trying to improve the working systems in order to reduce the emissions of harmful components to the atmosphere and the consumption of energy as well. Until recent years the two fundamental criteria uses in deciding the best pavement to be uses are economical and technical considerations whereas today the environmental impact must also be taken into consideration. In the road sector the main research goal is the development of new systems which allow reducing the manufacturing and the application temperatures of the bituminous mixes. Bituminous mixes are most commonly use all over the world in pavement construction. Most of the highway in India is flexible pavements, within which are included surfacing of various types and thickness. Various studies are under taken to improve the strength characteristics of bituminous surfaces by modifying bitumen grades, aggregate gradation mix proportion and by adding different additives to the bitumen.

First attempt to produce asphalt with bitumen that was formed by steam was carried out in 1959 by Prof. Ladis Csanyi at Iowa State University, US since then foaming technology has been used in different countries, including US, Australia and Europe.WMA technologies, such as, Aspha-min, WAM Foam, and Sasobit were developed during that time. Since the start of developing modern WMA technologies, a lot of experiments have been carried out to establish potential benefits of using WMA and evaluating the performance compared to traditional HMA. It is seen from various literature reviews that strength of paving mixes can be enhanced by using modified binders. Such binders also improve temperature susceptibility and help eliminating some common problems like bleeding in peak summer temperature. Keeping these facts in minds it was felt that efforts can be made to use some modifier material or bitumen additive.

As per MoRTH - Section 509, bituminous concrete for wearing course should be made with bitumen of viscosity grade-30 (VG-30) for nominal aggregate size $19 \mathrm{~mm}$ with bitumen content $5-6 \%$ having layer thickness $50-65 \mathrm{~mm}$ and for nominal aggregate size of $19 \mathrm{~mm}$ with bitumen content $5-7 \%$ having layer thickness $30-45 \mathrm{~mm}$. Bitumen VG-30 improves the performance of the binder to minimize the stress cracking that occurs at low temperature and plastic deformation at high temperature. Use of binders is a logical, practical and economical 
approach to meet required performance standard for pavement today. This enhances durability of existing road surfacing which results in reducing maintenance and surfacing operations.

The use of Warm mix additive - Rediset in bitumen VG-30 is to reduce the mixing and compaction temperature of Bituminous Concrete. The warm mix asphalt (WMA) is an asphalt mixture which is mixed at temperature lower than conventional hot mix asphalt (HMA). Typically, the mixing temperatures of Warm mix ranges from 100 to $130^{\circ} \mathrm{C}$ compared to the mixing temperatures of 150 to $160^{\circ} \mathrm{C}$ for Hot mix. Thus, Warm mix has been gaining increasing popularity in the recent years. Rising energy prices, global warming, and more stringent environmental regulations have resulted in an interest in Warm mix technologies as a mean to decrease the energy consumption and emissions associated with conventional hot mix production. When producing Hot Mix a lot of energy is used to heat the aggregate. This is not only costly but also generates a large amount of emissions. Rediset dose $1-2 \%$ enables the production of Warm mix $30-40^{\circ} \mathrm{C}$ lower temperature than hot mix and this will reduce fuel consumption by at least $20 \%$ and significantly lower emissions not only at the hot-mix plant but also at the paving site. The following fig. shows the various technologies classification related to various temperatures.

The attempt of use of binders is a logical, practical and economical approach to meet the required performance standard for pavement construction nowadays. This enhancement in durability results in the reduction of maintenance and surface operation.

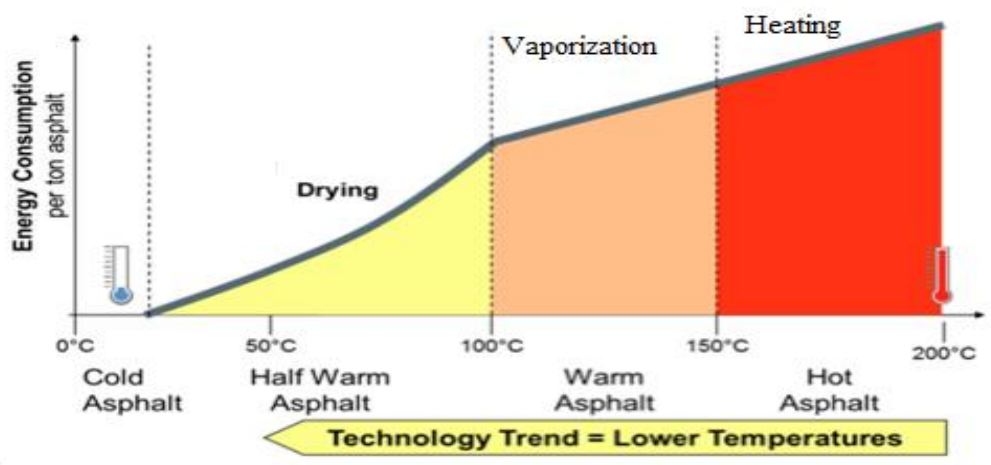

Fig. 1 classification of technologies related to various temp.

\section{Study Methodology}

In this study bituminous concrete for pavement is designed for the $20 \mathrm{~mm}$ nominal size aggregate. The bitumen of VG-30 grade used as binder and aggregates are crushed aggregate from quarry.

At the first the laboratory testing is carried out to find the physical properties of aggregate by conducting tests like Aggregate Impact value, Abrasion Test, Crushing value test, Flakiness and elongation Index (combined), Water absorption, Specific Gravity, Grain size analysis etc. As per MORTH section 500 clause 509 the gradation of $20 \mathrm{~mm}$ size aggregate is decided. Same for the tests of bitumen of VG-30 grade with and without rediset including penetration test, specific gravity, softening test, elastic Recovery Test, Viscosity etc. which satisfy the requirement of IS:73-2013 "SPECIFICATION OF BITUMEN".

On the second part of the study samples for Marshall Mix design are prepared and the optimum binder content for BC using bitumen of VG-30 can be determined. After this the sample at temperature $110^{\circ} \mathrm{C}, 120^{\circ} \mathrm{C}$ and $130^{\circ} \mathrm{C}$ with different doses of Rediset-WMX. Based on these samples the optimum temperature and optimum doses of rediset can be determined for binder.

The following fig. shows the methodology chart below.

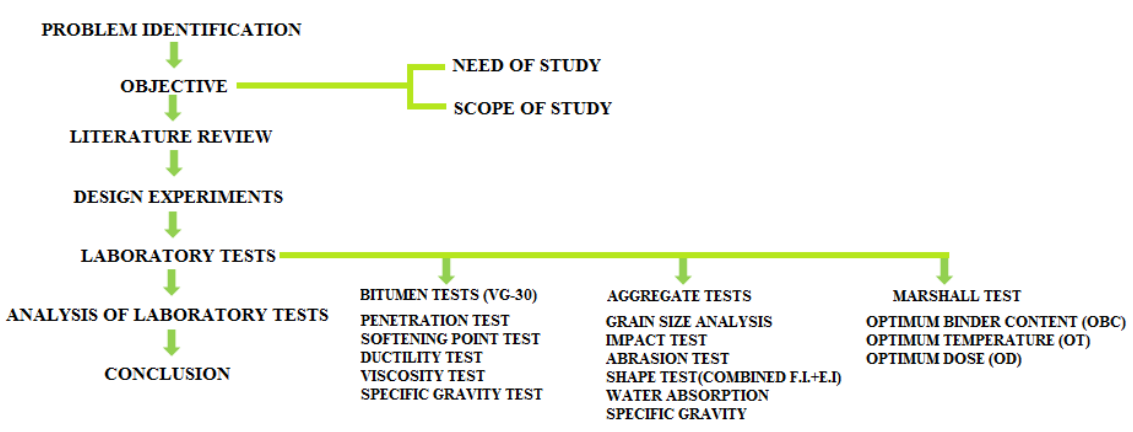

Fig. 2 study methodology 


\subsection{Materials}

\section{Literature Review}

\subsubsection{Rediset-WMX}

In this study, REDISET-WMX which is a chemical technology but organic material in the form of pellet and does not contain water is used. REDISET-WMX is the combination of cationic surfactants and organic additive based rheology modifier. It chemically modifies the bitumen and encourages active adhesion that improves the wetting of aggregates by binder. Other components of the additive reduce the viscosity of the binder at production temperature. The producer of Rediset-WMX is AkzoNobel India Ltd. claims that by using Rediset-WMX the wetting ability of asphalt binder can be improve for better coating with aggregates, and this also reduce the viscosity and make the binder lubricating for better coating easy compaction. By addition of 1.5$2.0 \%$ by weight of bitumen, it allows $15^{\circ}-30^{\circ} \mathrm{C}$ production temperature reduction compared to HMA. From the different technologies of the WMA we are using the Rediset- WMX, as the rediset is effortlessly available in our state easily and it is economically adopted for the design of the pavement. The following fig. shows the actual image of the Rediset-WMX.

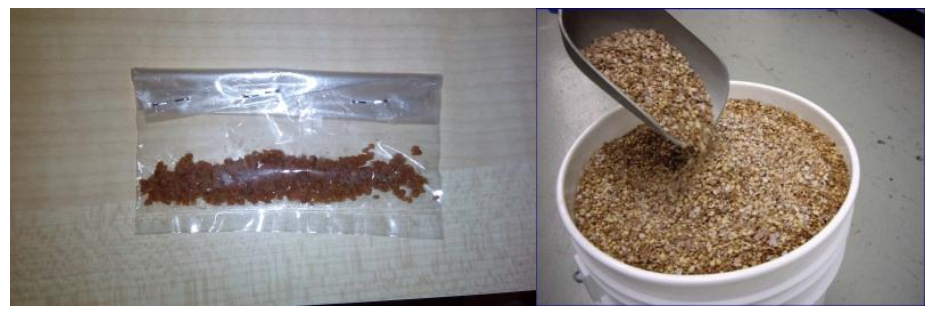

Fig. 3 photograph of Rediset-WMX

\subsubsection{Aggregates}

The aggregates used in this design of $\mathrm{BC}$ are $6 \mathrm{~mm}$ and $20 \mathrm{~mm}$ nominal size aggregates. They are graded as per MORTH section 500 clause 509 which satisfy the requirement for design of BC. The aggregates are clean, cubic shape and rough texture to resist fracture of pavement under heavy traffic loads.

The aggregates taken should passed $20 \mathrm{~mm}$ sieve and retained on 75 micron IS sieve should be taken into the consideration while design the $\mathrm{BC}$.

\subsubsection{Bitumen}

The bitumen used for the mix is of the viscosity grade-30 (VG-30). This VG-30 grade binder is used for the construction of heavy duty flexible pavement. These heavy duty flexible pavements are constructed for the tolerance of extensive traffic loads. The VG-30 can also be used in substitution for 60-70 penetration grades.

\subsection{Additional technology of wma \& their different products}

After the first evolution of warm mix asphalt technology in 1959 by Prof. Ladis Csanyi at Iowa State University, till now there are many technologies have come on rise. The additional technologies available for the pavement construction are divided in to three categories which are listed below.

1. Use of Chemical Technologies

2. Use of Foaming Technologies

3. Use of Organic(Wax) Additives

The various additives of different technologies are listed below in the Table along with their specific temperature reduction.

Table 1 Various additives of different technologies

\begin{tabular}{|c|c|c|c|c|c|}
\hline Product & Company & Description & $\begin{array}{c}\text { Reports Form } \\
\text { Countries }\end{array}$ & Additive & $\begin{array}{c}\text { Production Temperature } \\
\text { (Reduction Range) }\end{array}$ \\
\hline \multicolumn{7}{|c|}{ Foaming technology } \\
\hline $\begin{array}{c}\text { Double Barrel } \\
\text { Green }\end{array}$ & Astec & $\begin{array}{c}\text { Water based foaming } \\
\text { process }\end{array}$ & U.S. & $\begin{array}{c}\text { By choice, Anti- } \\
\text { stripping agent }\end{array}$ & $116^{\circ} \mathrm{TO} 135^{\circ} \mathrm{C}$ \\
\hline $\begin{array}{c}\text { Low energy } \\
\text { asphalt }\end{array}$ & LEACO & $\begin{array}{c}\text { water based hot coarse } \\
\text { aggregate mixed with } \\
\text { wet sand }\end{array}$ & U.S., France, Spain & $\begin{array}{c} \pm 0.5 \% \text { of } \\
\text { bitumen coating } \\
\text { adhesion }\end{array}$ & $\leq 100^{\circ} \mathrm{C} \& 105^{\circ}$ to $124^{\circ} \mathrm{C}$ \\
\hline \multicolumn{7}{|c|}{ Chemical technology } & Not Specified & $85^{\circ}$ to $115^{\circ} \mathrm{C}$ \\
\hline Evotherm 3G & Mead-Westvaco & $\begin{array}{c}\text { Water free } \\
\text { chemical package }\end{array}$ & U.S. & \\
\hline
\end{tabular}


A study on Warm mix asphalt technology on bituminous mixes using Rediset-WMX

\begin{tabular}{|c|c|c|c|c|c|} 
Rediset WMX & Akzo - Nobel & $\begin{array}{c}\text { cationic } \\
\text { surfactants and } \\
\text { organic additive }\end{array}$ & U.S. & $\begin{array}{c}1.5-2 \% \text { of } \\
\text { bitumen } \\
\text { weight }\end{array}$ & \multicolumn{2}{c|}{ Organic Technology } \\
\hline Sasobit & Sasol & $\begin{array}{c}\text { Fischer-Tropsch } \\
\text { wax }\end{array}$ & $\begin{array}{c}\text { U.S, EU, } \\
\text { worldwide }\end{array}$ & $\begin{array}{c}1.0-3.0 \% \text { of } \\
\text { bitumen }\end{array}$ & $\begin{array}{c}126^{\circ} \mathrm{C} \\
130^{\circ} \text { to } 150^{\circ} \mathrm{C} \\
\text { bitumen of } \\
\text { weight }\end{array}$ \\
\hline $\begin{array}{c}\text { Asphaltan A } \\
\text { Romonta N }\end{array}$ & Romonta GmbH & $\begin{array}{c}\text { Montan wax for } \\
\text { mastic asphalt }\end{array}$ & Germany & Reduction up to $20^{\circ} \mathrm{C}$ \\
\hline
\end{tabular}

\subsection{Previous studies on warm mix asphalt technology}

Hurley and Prowell, 2005 evaluated three different WMA additives: Aspha-Min ${ }^{\circledR}$ (synthetic zeolite), Sasobit ${ }^{\circledR}$ (wax) and Evotherm ${ }^{\mathrm{TM}}$ (emulsion) and concluded that all three technologies improved the asphalt mixture compatibility and resulted in reduction of air voids as compared to HMA. They stated that the addition of Aspha-min lowered the air voids in WMA measured in the rotating compactor. This can also improve the compatibility of both the rotating compactor and a vibratory compactor. Arithmetical analyses of test results indicated an average reduction in air voids of $0.65 \%$ using the vibratory compactor. Aspha-min did not have any significant effect on the resilient modulus of asphalt mixtures.

Dr. Sunil Bose, Mrs. Ambika Behl, Mr. M.N.Nagabhushna, Mr. Gajendra Kumar, Mr. Girish Sharma, Mrs. R. Uma Devi- Laboratory Evaluation of Evotherm Additive in Warm Mixes (2011) carried out study on use of Evotherm Additives to design Warm mix design of Bituminous concrete with $13 \mathrm{~mm}$ nominal size of aggregate by adding $0.5 \%$ by weight of binder ( $60 / 70$ Grade).The Marshall sample prepared at $95-100^{\circ} \mathrm{C}, 105-$ $110^{\circ} \mathrm{C}, 115-120^{\circ} \mathrm{C}$ and $125-130^{\circ} \mathrm{C}$ temperature gives the $\mathrm{OBC} 5.7 \%$. The performance Evaluation tests also carried out at each of above temperature such as Retained Stability, Indirect Tensile Strength and Tensile Strength Ratio, Hamburg Wheel Tracking Rutting test to obtain Temperature at which the Warm mix satisfactorily gives its performance. The Retained stability for Control mix is $82.5 \%$ and $85.15 \%, 79.33 \%$, $78.4 \%$ and $77.27 \%$ respectively for above temperature which is higher than required $75 \%$ as per MORTH section 500 clause 509. Tensile Strength Ratio for Control mix is $85.2 \%$ and $86.3 \%, 85.2 \%, 83.8 \%$ and $77.8 \%$ respectively in which the Tensile Strength Ratio at temperature $95-100^{\circ} \mathrm{C}$ is lower than required $80 \%$ as per MORTH section 500 clauses 509. Rutting test indicate that the rutting at $125-130^{\circ} \mathrm{C}$ temperature is 1.8 times lesser than the Control mix. At the end of Research they concluded that the There is no saving in OBC using Evotherm as additive.

MUNSHI RAMIZRAJA, from SVNIT, Surat (2011) conducted a study on warm mixed design on bitumen concrete using modified binders. In this study he was carried out polymer modified binder (PMB) and crumb rubber modified binder (CRMB) used as a modified binder. The grade of this modified binder is PMB 40 and CRMB 60 used. In this study, he used $2 \%$ Rediset WMX with this modified binders. The reduction of $30^{\circ}$ to $40^{\circ} \mathrm{C}$ has been documented in mixing and compaction temperature of bituminous mixes by adding $2 \%$ additive and fulfilled all volumetric requirement for both binders resulting in better performance at lower temperature of bituminous mixes. Bituminous mixes are less vulnerable to entrance of water or moisture damage than conventional mixes because of increasing in retained stability and tensile strength ratio of warm mix using both binders. Under static loads the permanent deformation of warm mix is lower than the control mix and have higher rate of recovery at higher temperature indicating better resistance to permanent deformation. Warm Bituminous mix with Polymer as well as Crumb rubber modified bitumen having higher fatigue life than conventional mix due to higher initial stiffness which indicate higher resistance to fatigue failure which occur at lower temperature. Warm Bituminous mix with Polymer modified bitumen exposed to lesser rutting than conventional mix which entitles the higher resistance to the deformation under wheel path.

\section{Laboratory Tests}

The warm mix design of the bituminous concrete starts with the laboratory tests originated by finding the physical properties of aggregate and bitumen which must satisfied the requirement of MORTH specification and relevant IS codes. Subsequently this determination of physical properties the Marshall Stability test for the determination of $\mathrm{OBC}$ as well as optimum temperature and optimum doses of the Rediset for making the $\mathrm{BC}$ is 
carried out. At last the testing for certain engineering properties of controlled along with warm mix using binder of VG-30 can be carried out for checking the specification.

\title{
4.1 Aggregate testing
}

Aggregates used in this study of designing the $\mathrm{BC}$ is crushed aggregate collected from the quarry. Before using the aggregate in design of bituminous mix it has been tested for their physical properties consist of Hardness, Toughness, Cleanliness, Particle shape, Water absorption, Stripping etc. These test should be performed as per procedure revealed in the applicable IS codes. The tests performed on the aggregate in the laboratory are as follows:

$\wp \quad$ Grain size analysis, IS: 2386 (Part 1)-1963

$\wp \quad$ Impact value test, IS: 2386 (Part 4)-1963

$\wp \quad$ Shape test, IS: 2386 (Part 1)-1963

$\wp \quad$ Abrasion test IS: 2386 (Part 4)-1963

$\wp \quad$ Water absorption and Specific Gravity test, IS: 2386 (Part 3)-1963

\subsection{Bitumen tests}

Bitumen used in the warm as well as control design of BC is VG-30. Bitumen is used to bind the material together. Before use of bitumen in design mix it has been tested for their physical properties. All these test should be performed as per procedure in relevant IS codes. The tests to be performed are enlisted as follows:

\author{
$\wp \quad$ Penetration test, IS: 1203-1978 \\ $\wp \quad$ Softening Point test, IS: 1205-1978 \\ $\wp \quad$ Ductility test, IS: $1208-1978$ \\ $\wp \quad$ Viscosity test, IS: $1206-1978$ \\ $\wp \quad$ Specific Gravity test, IS: $1202-1978$
}

\subsection{Marshall stability test}

The Marshall Stability and flow test provides the performance and prediction measure for the marshall mix design method. The stability portion of the test measures the maximum load supported by the test specimen at a loading rate of $50.8 \mathrm{~mm} /$ minute. Load is applied to the specimen till failure, and the maximum load is designed as stability. During the loading, an attached dial gauge measures the specimen's plastic flow (deformation) due to loading. The flow value is recorded in $0.25 \mathrm{~mm}(0.01 \mathrm{inch})$ increments at the same time when the maximum load is recorded. The properties incorporated with the test are stability, flow value, bulk specific gravity, air voids, voids filled with bitumen, voids in mineral aggregates. The marshall test also gives the final blend of the materials to be used. The Marshall Stability Test gives the following:
$\wp \quad$ Optimum Binder Content
$\wp \quad$ Optimum Dose of Rediset-WMX
$\wp \quad$ Optimum Temperature

\subsubsection{Sample Preparation Schedule}

For warm mix design of $\mathrm{BC}$ mixes it has to prepare samples for Marshall Mix design and performance evaluation tests. The following Table describes the sample prepared for Marshall Stability test.

Table 2 Sample preparation schedule

\begin{tabular}{|c|c|c|}
\hline SR NO. & TYPES OF TESTS & NO. OF SAMPLE \\
\hline 1 & Marshall test for OBC & 9 \\
\hline 2 & Marshall test for Optimum dose of Rediset-WMX and OT & 27 \\
\hline
\end{tabular}

\section{Analysis Of Tests Results}

Laboratory test results has been evaluated to predict the behaviour of warm mix as well as control mix and to investigate the use of Rediset in bituminous mixes has superior over control mix. Analysis of tests results start from the analysis of aggregate and bitumen test results, which satisfied all the recommendation of MORTH section 500 clause 509 .

Secondly, a volumetric property of Marshall Mix design has been analyzed. Also, results of optimum temperature and optimum dose of Rediset has been analyzed while comparing with stability, bulk density and air voids.

\subsection{Aggregate Tests}

Aggregate used in the study has been tested as per the procedure given in relevant IS codes. 
All these tests should satisfy the requirement given in MORTH section 500 clause 509 Table 500-17. Test results of aggregate shown in Table below.

From above Table it should clearly see that aggregate used in the study satisfied the entire requirement which indicate that the aggregate having all the required physical properties. Therefore, study has been continued further along with this aggregate.

Table 3 Analysis of aggregate tests results

\begin{tabular}{|c|c|c|c|}
\hline \multicolumn{4}{|c|}{ Aggregate tests } \\
\hline Sr. No. & Test & Result & Recommended Value as per MORTH \\
\hline 1 & Grain size analysis & $2.11 \%$ & Max 5\% passing $0.075 \mathrm{~mm}$ IS Sieve \\
\hline 2 & Impact Value Test & $15.87 \%$ & $24 \%$ MAX \\
\hline 3 & Abrasion Test & $14.83 \%$ & $30 \%$ MAX \\
\hline 4 & Shape Test & $28.25 \%$ & $30 \%$ MAX (combined) \\
\hline \multirow[t]{3}{*}{5} & \multirow[t]{3}{*}{ Water Absorption Test } & $1.67 \%(20 \mathrm{~mm})$ & \multirow[t]{3}{*}{$2 \%$ MAX } \\
\hline & & $1.26 \%(6 \mathrm{~mm})$ & \\
\hline & & $1.63 \%$ (Stone Dust) & \\
\hline \multirow[t]{3}{*}{6} & \multirow[t]{3}{*}{ Specific Gravity } & $2.16(20 \mathrm{~mm})$ & \multirow[t]{3}{*}{---} \\
\hline & & $1.78(6 \mathrm{~mm})$ & \\
\hline & & 1.27 (Stone Dust) & \\
\hline
\end{tabular}

\subsection{Bitumen tests}

Bitumen used in the study is VG-30 which has been tested as per procedure given in relevant IS codes. All the tests must satisfy the requirement of physical properties of Binders as per IS: 73-2013. The test results of binder used in the study shown in Table below. A test result of binder clearly shows that they satisfied all the requirement of binder for with and without Rediset. The testing results of plain bitumen show significant values which fulfil the requirements of relevant IS limits, hence the bitumen is appropriate to use for the Marshall mix design of bituminous concrete.

Table 4 Analysis of bitumen tests results

\begin{tabular}{|c|c|c|c|c|c|c|}
\hline \multicolumn{7}{|c|}{ Bitumen test } \\
\hline $\begin{array}{l}\text { Sr. } \\
\text { No }\end{array}$ & Test & $\begin{array}{l}\text { VG } \\
\text { 30 }\end{array}$ & $\begin{array}{l}\text { VG 30+1.5\% } \\
\text { Rediset-WMX }\end{array}$ & $\begin{array}{l}\text { VG 30+2.0\% } \\
\text { Rediset-WMX }\end{array}$ & $\begin{array}{l}\text { VG 30+2.5\% } \\
\text { Rediset-WMX }\end{array}$ & $\begin{array}{l}\text { Recommendation } \\
\text { as per IS 73:2013 }\end{array}$ \\
\hline 1 & $\begin{array}{l}\text { Penetration Test at } \\
25^{\circ} \mathrm{C}, 0.1 \mathrm{~mm}, 5 \\
\text { sec }\end{array}$ & 64.5 & 66.6 & 65.7 & 68.6 & $50-70$ \\
\hline 2 & $\begin{array}{l}\text { Softening Point } \\
\text { Test at, }{ }^{\circ} \mathrm{C} \text {, Min }\end{array}$ & 56.2 & 54.3 & 53.1 & 52.6 & 47 \\
\hline 3 & $\begin{array}{l}\text { Ductility Test, } \\
\qquad 25^{\circ} \mathrm{C}\end{array}$ & $70+$ & $70+$ & $70+$ & $70+$ & 40 \\
\hline 4 & $\begin{array}{c}\text { Viscosity Test, } \\
60^{\circ} \mathrm{C} \text {, Poise, Min. }\end{array}$ & 2485 & 2468 & 2440 & 2427 & 2400-3600 \\
\hline 5 & $\begin{array}{c}\text { Specific Gravity } \\
\text { Test }\end{array}$ & 1.09 & 1.06 & 1.13 & 1.01 & --- \\
\hline
\end{tabular}

\subsection{Gradation of aggregate}

The sieve analysis test of the material is carried out for the aggregates to be tested for their physical properties and grading of aggregate is to be determining for mix design which must satisfied the MORTH requirement for $20 \mathrm{~mm}$ nominal size of aggregate. The final blend for gradation aggregate used in the study shown in Table below along with the MORTH recommended values. The graph plotted also shown below in fig. 4. From the belowTable it is clearly seen that final gradation within upper and lower limit of $20 \mathrm{~mm}$ nominal size aggregate. Now, the entire sample should be prepared by adopting this gradation of aggregate. 
Table 5 Gradation of aggregate used

\begin{tabular}{|c|c|c|c|c|c|c|c|}
\hline \multicolumn{8}{|c|}{ Gradation } \\
\hline \multirow{2}{*}{ Sieve Size(mm) } & $19 \mathrm{~mm}$ & $6 \mathrm{~mm}$ & Stone Dust & Lime & Blend & \multirow{2}{*}{$\begin{array}{c}\text { Upper } \\
\text { limit }\end{array}$} & \multirow{2}{*}{$\begin{array}{l}\text { Lower } \\
\text { limit }\end{array}$} \\
\hline & $45 \%$ & $26 \%$ & $26 \%$ & $3 \%$ & $100 \%$ & & \\
\hline 19 & 100 & 100 & 100 & 100 & 100 & 100 & 79 \\
\hline 13.2 & 41 & 100 & 100 & 100 & 73 & 79 & 59 \\
\hline 9.5 & 1 & 97 & 100 & 100 & 55 & 72 & 52 \\
\hline 4.75 & 0 & 45 & 91 & 100 & 38 & 55 & 35 \\
\hline 2.36 & 0 & 4 & 90 & 100 & 28 & 44 & 28 \\
\hline 1.18 & 0 & 0 & 66 & 100 & 20 & 34 & 20 \\
\hline 0.6 & 0 & 0 & 59 & 100 & 18 & 27 & 15 \\
\hline 0.3 & 0 & 0 & 32 & 99 & 12 & 20 & 10 \\
\hline 0.15 & 0 & 0 & 20 & 91 & 8 & 13 & 5 \\
\hline 0.075 & 0 & 0 & 2 & 65 & 3 & 8 & 2 \\
\hline
\end{tabular}

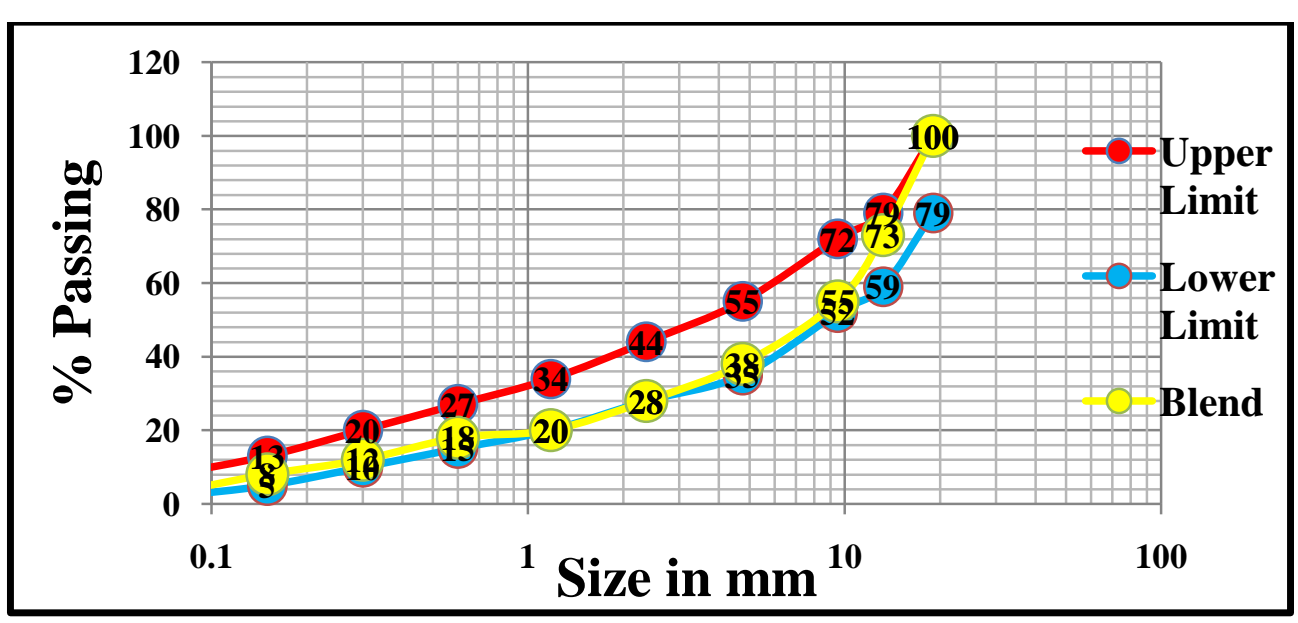

Fig. 4 Grading of aggregate

\subsection{Marshall mix design}

Marshall Mix design for BC mixes using warm mix technology includes the determination of OBC and then OT and as well as optimum dose of Rediset-WMX for bitumen.

\subsubsection{Optimum binder content}

The optimum binder content of BC can be determined by performing Marshall Test on sample prepared at various binder content. From the above data recorded, it has been clearly seen that design mix satisfied the all volumetric requirement of BC as per MORTH section 500, clause 509. The results of Marshall Stability test for $\mathrm{OBC}$ are shown in Table below.

Table 6Volumetric properties of BC mix using VG-30

\begin{tabular}{|c|c|c|c|c|c|c|c|}
\hline $\begin{array}{c}\text { SR. } \\
\text { NO. }\end{array}$ & Bitumen (\%) & Stability (KG) & Flow value (mm) & Bulk density (gm/cc) & $\begin{array}{c}\text { Vv } \\
(\%)\end{array}$ & $\begin{array}{c}\text { VFB } \\
(\%)\end{array}$ & VMA (\%) \\
\hline 1 & 5 & 1616 & 3.37 & 2.35 & 4.69 & 69.9 & 15.57 \\
\hline 2 & 5.5 & 1754 & 4.1 & 2.36 & 3.36 & 78.11 & 15.29 \\
\hline 3 & 6 & 1733 & 5.23 & 2.34 & 3.21 & 75 & 16.07 \\
\hline
\end{tabular}




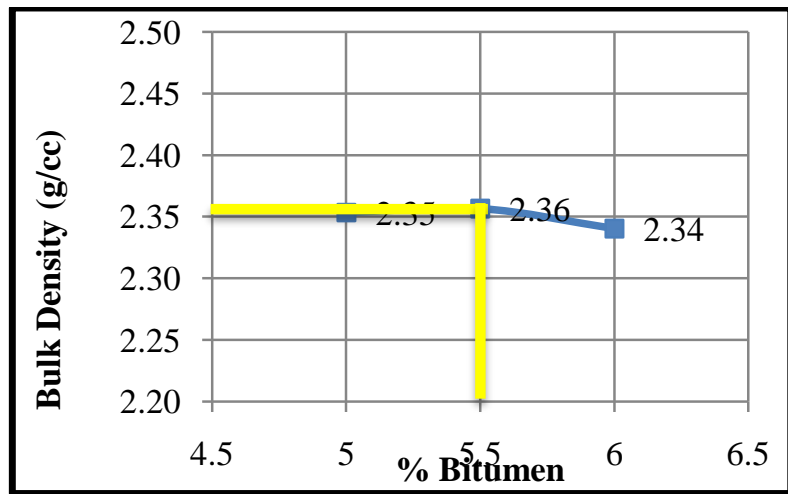

Fig. 5 Bulk density Vs. \% bitumen

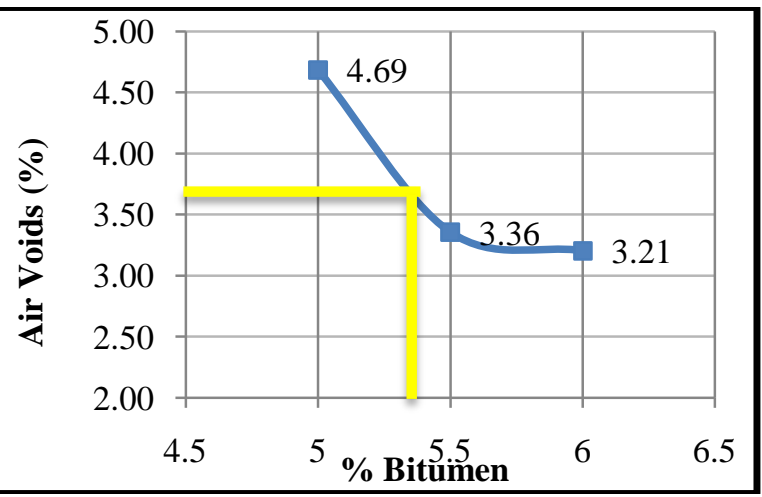

Fig. 6 Air voids Vs. \% bitumen

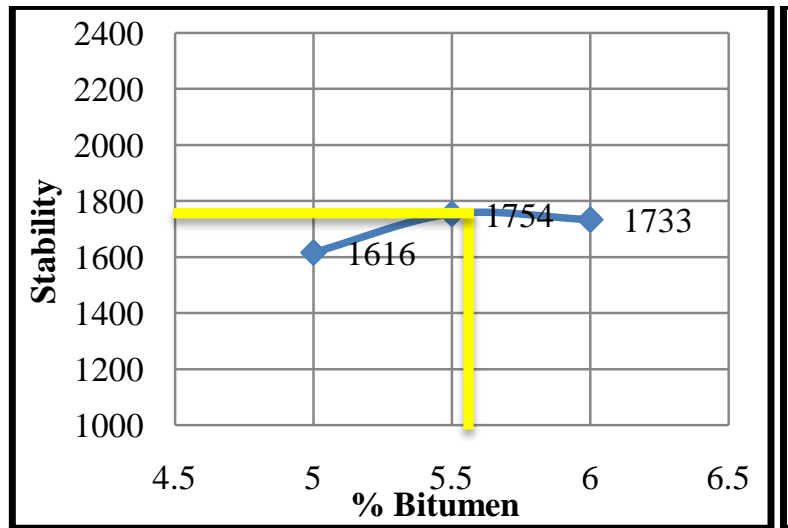

Fig. 7 Stability Vs. \% bitumen

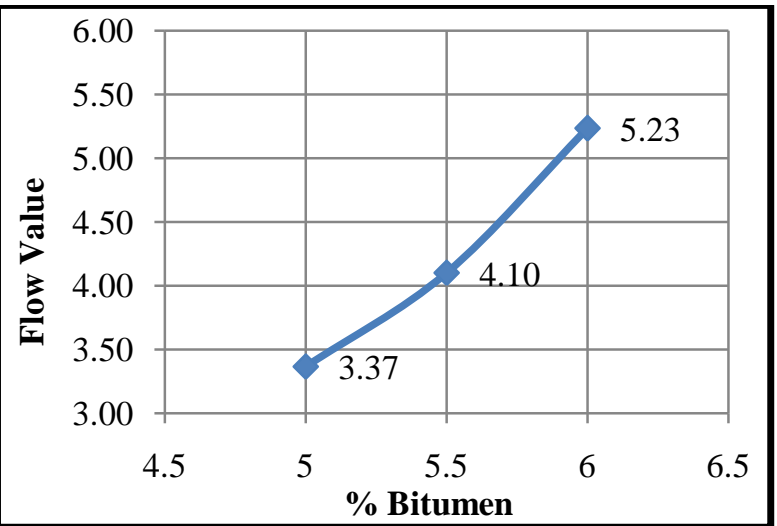

Fig. 8 Flow Value Vs. \% bitumen

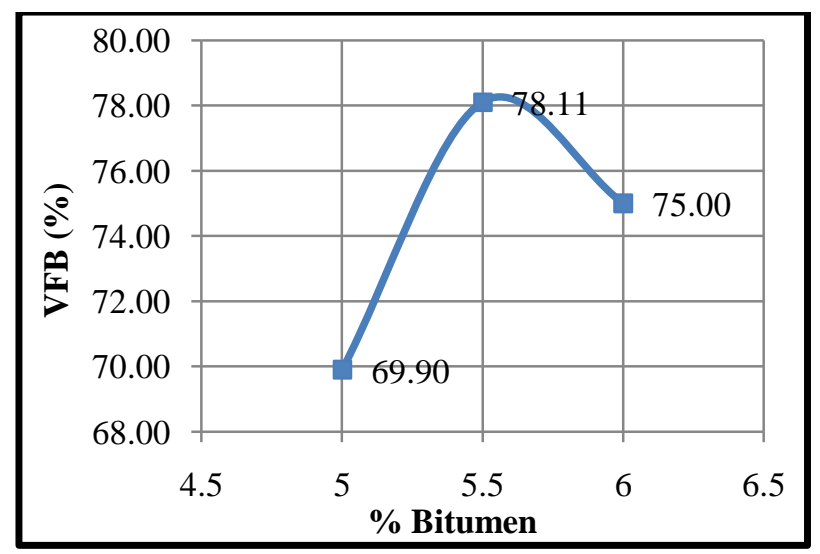

Fig. 9 Voids filled with bitumen Vs. \% bitumen

Based on the properties of mixes the graph has been plotted shown in fig. 5, 6, 7, 8, and 9. The optimum binder content can be determined by taking average of these values ( $\min 3$ values). The following Table shows the average optimum binder content of the mix.

Table7Average OBC OF BC MIX USING VG-30

\begin{tabular}{|c|c|c|}
\hline Sr. No. & Description & Bitumen \\
\hline 1 & Bitumen content corresponding to maximum stability & 5.5 \\
\hline 2 & Bitumen content corresponding to maximum bulk density & 5.5 \\
\hline 3 & Bitumen content corresponding to air voids (Vv) in total mix & 5.3 \\
\hline \multicolumn{2}{|c|}{ Average } & 5.43 \\
\hline
\end{tabular}

\subsubsection{Optimum Temperature And Optimum Dose Of Bitumen}

Test results of $\mathrm{BC}$ using VG-30 by addition of $1.5,2$ and $2.5 \%$ Rediset at a temperature $110^{\circ} \mathrm{C}$, $120^{\circ} \mathrm{C}$, and $130^{\circ} \mathrm{C}$ along with their volumetric properties has shown in Table below. 
Table 8Volumetric properties of BC mix using VG-30+1.5\% Rediset-WMX

\begin{tabular}{|c|c|c|c|c|c|c|c|}
\hline $\begin{array}{c}\text { SR. } \\
\text { NO. }\end{array}$ & $\begin{array}{c}\text { Temperature } \\
\left({ }^{\mathbf{C}} \mathbf{C}\right)\end{array}$ & $\begin{array}{c}\text { Stability } \\
(\mathbf{K G})\end{array}$ & $\begin{array}{c}\text { Flow value } \\
(\mathbf{m m})\end{array}$ & $\begin{array}{c}\text { Bulk density } \\
(\mathbf{g m} / \mathbf{c c})\end{array}$ & $\begin{array}{c}\mathbf{V} \mathbf{6} \\
(\mathbf{\%})\end{array}$ & $\begin{array}{c}\text { VFB } \\
(\boldsymbol{\%})\end{array}$ & $\begin{array}{c}\text { VMA } \\
(\boldsymbol{\%})\end{array}$ \\
\hline 1 & 110 & 883 & 3.6 & 2.30 & 5.7 & 67.17 & 17.36 \\
\hline 2 & 120 & 1056 & 4.7 & 2.34 & 4.16 & 73.59 & 16 \\
\hline 3 & 130 & 991 & 4.7 & 2.32 & 4.93 & 70.47 & 16.68 \\
\hline
\end{tabular}

Table9 Volumetric properties of BC mix using VG-30+2.0\% Rediset-WMX

\begin{tabular}{|c|c|c|c|c|c|c|c|}
\hline $\begin{array}{c}\text { SR. } \\
\text { NO. }\end{array}$ & $\begin{array}{c}\text { Temperature } \\
\left({ }^{\circ} \mathbf{C}\right)\end{array}$ & $\begin{array}{c}\text { Stability } \\
(\mathbf{K G})\end{array}$ & Flow value $(\mathbf{m m})$ & $\begin{array}{c}\text { Bulk } \\
\text { density }(\mathbf{g m} / \mathbf{c c})\end{array}$ & $\begin{array}{c}\text { Vv } \\
(\boldsymbol{\%})\end{array}$ & $\begin{array}{c}\text { VFB } \\
(\boldsymbol{\%})\end{array}$ & $\begin{array}{c}\text { VMA } \\
(\boldsymbol{\%})\end{array}$ \\
\hline 1 & 110 & 1124 & 4.1 & 2.31 & 5.5 & 68.06 & 17.2 \\
\hline 2 & 120 & 1656 & 3.6 & 2.33 & 4.45 & 72.7 & 16.25 \\
\hline 3 & 130 & 1487 & 3.9 & 2.32 & 5.21 & 69.31 & 16.96 \\
\hline
\end{tabular}

Table10 Volumetric properties of BC mix using VG-30+2.5\% Rediset-WMX

\begin{tabular}{|c|c|c|c|c|c|c|c|}
\hline $\begin{array}{c}\text { SR. } \\
\text { NO. }\end{array}$ & $\begin{array}{c}\text { Temperature } \\
\left({ }^{\circ} \mathbf{C}\right)\end{array}$ & $\begin{array}{c}\text { Stability } \\
(\mathbf{K G})\end{array}$ & $\begin{array}{c}\text { Flow value } \\
(\mathbf{m m})\end{array}$ & $\begin{array}{c}\text { Bulk } \\
\text { density }(\mathbf{g m} / \mathbf{c c})\end{array}$ & $\begin{array}{c}\text { Vv } \\
(\mathbf{\%})\end{array}$ & $\begin{array}{c}\text { VFB } \\
(\boldsymbol{\%})\end{array}$ & $\begin{array}{c}\text { VMA } \\
(\mathbf{\%})\end{array}$ \\
\hline 1 & 110 & 1067 & 3.8 & 2.3 & 5.44 & 63.16 & 17.09 \\
\hline 2 & 120 & 1272 & 4.8 & 2.33 & 4.63 & 71.79 & 16.42 \\
\hline 3 & 130 & 1146 & 3.6 & 2.32 & 4.75 & 71.24 & 16.52 \\
\hline
\end{tabular}

Based on the value obtained after Marshall Test for OT and OD, the graphs have been plotted according to the corresponding values to the temperature. The graphs plotted have been shown below in fig.10, 11 and 12 respectively.

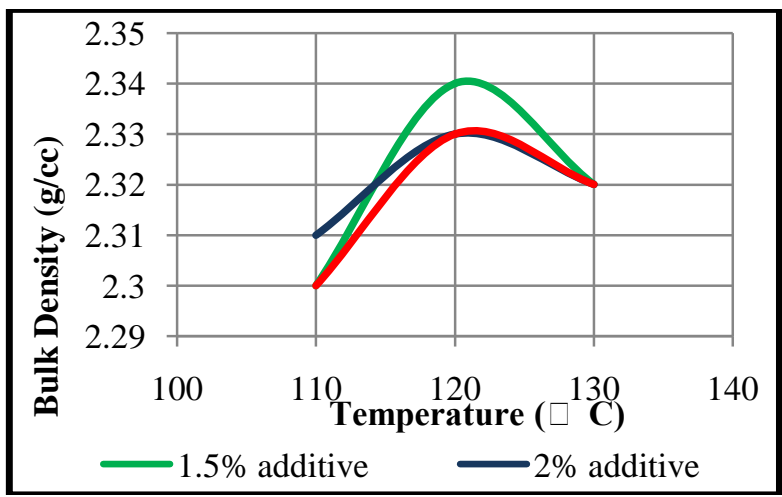

Fig. 10 Bulk density Vs. Temperature

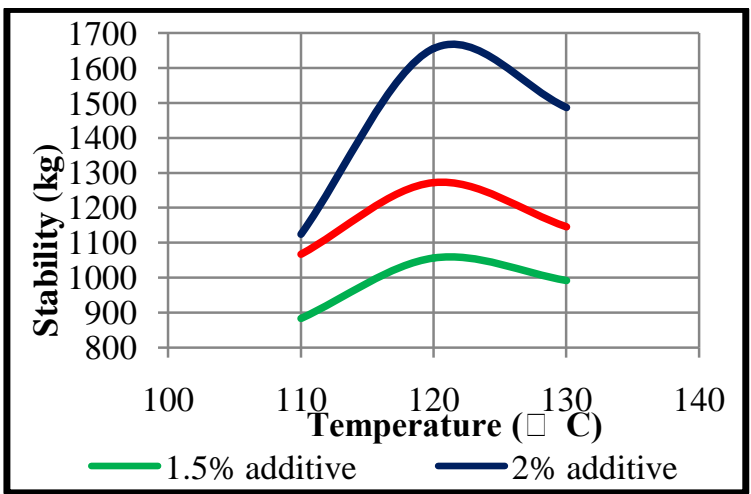

Fig. 11 Stability Vs. Temperature

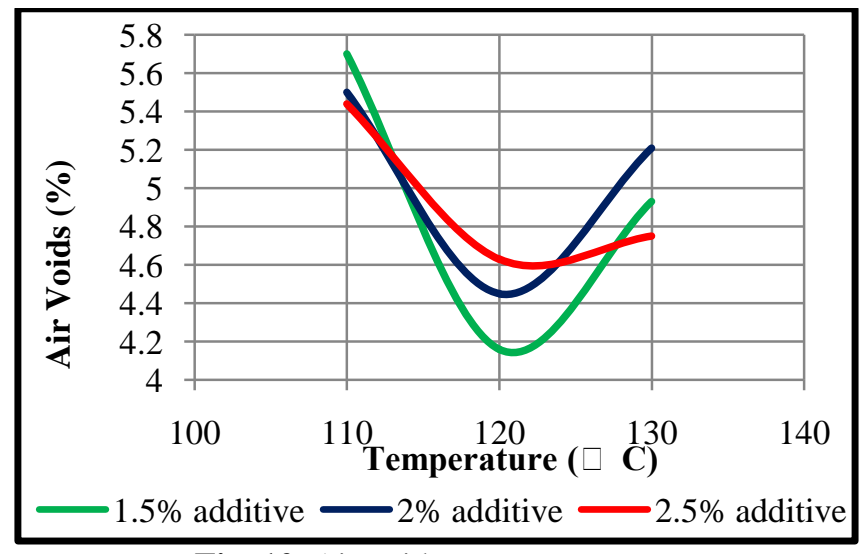

Fig. 12 Air voids Vs. Temperature

From the above fig. it is clearly seen that $2 \%$ dose of the Rediset-WMX gives higer bulkdensity and stability than other two doses at the temperature of $120^{\circ} \mathrm{C}$ and the $\%$ of air voids are also low in the $2 \%$ dose at $120^{\circ} \mathrm{C}$ temperature. Hence from the above graphs the optimum dose of Rediset-WMX is taken as $2 \%$ and the 
optimum temperature is taken as $120^{\circ} \mathrm{C}$. Addition of $1.5 \%$ rediset reduces the stability at that temperature. The addition of $1.5 \%$ Rediset causes reduction in stability which obviously lower than the MoRTH requirement except at $120^{\circ} \mathrm{C}$ temperature. Similarly the addition of $2.5 \%$ rediset reduces the VFB at $110^{\circ} \mathrm{C}$ temperature which is slightly lower than MORTH requirement.

\section{Cost Analysis}

Warm mix technology of bituminous mix using VG-30 as binder and Rediset-WMX as additive gives the satisfactory performance as per the laboratory test analysis. In the actual world it has been noted that the price or cost of making or manufacturing the same take us away to use the method of manufacturing. So it necessary performs cost analysis of this technology in order to accept the technology in the actual world or field. In India the method of making the same does not give preference but the cost of making the same take more preference. In this case study the attempt has been made to analyze the cost in terms of fuel saving and addition of $2 \%$ rediset in bituminous mixes, because as per most of the research papers there would be $20 \%$ saving in the fuel by using this technology. The following Table shows the price of different material used in preparation of BC.

Table8 Price of different materials

\begin{tabular}{|c|c|c|}
\hline Sr. No. & Materials & Price \\
\hline 1 & Light Diesel Oil & $77.92 /$ litre (HPCL Price) \\
\hline 2 & Rediset-WMX & $150 /$ KG \\
\hline
\end{tabular}

\subsection{Calculation}

Calculation has been carried out to prepare control bituminous mixes using warm mix technology for $1 \mathrm{~m}^{3}$ at hot mix plant.
6.1.1. Addition of $2 \%$ Rediset-WMX by weight of binder
$\wp \quad$ Density of mix $=2330 \mathrm{Kg} / \mathrm{cum}$
$\wp$ Volume of $\operatorname{mix}=1$ cum.
$\wp \quad$ Weight of mix required $=2330 \mathrm{Kg}$
ø Optimum binder content $=5.43 \%$
$\wp \quad$ Bitumen required for prepared bituminous mix @ OBC $5.43 \%=126.519 \mathrm{Kg}$
$\wp \quad$ Addition of $2 \%$ rediset by weight of bitumen per $\mathrm{m} 3=2.53 \mathrm{~kg}$
$\wp \quad$ Addition of cost of Rediset-WMX to prepared mix @ 150/Kg per m3=380 Rs.

\subsubsection{Saving In Fuel Consumption}

$\wp$ LDO required to prepared control bituminous mix at $160^{\circ} \mathrm{C}$ temperature per Cum. $=19.8$ liter

$\wp$ LDO required to prepared Warm bituminous mix at $120^{\circ} \mathrm{C}$ temperature per Cum. $=14.4$ liter

$\wp$ Saving in LDO to prepare bituminous mix using warm mix technology at $120^{\circ} \mathrm{C}$ temperature per cum $=4.8$ liter.

$\wp \quad$ Saving in cost of LDO to prepared warm bituminous mix at $120^{\circ} \mathrm{C}$ temperature @ 77.92 Rs. / Liter per Cum. $=374.017$ Rs / cum.

\subsubsection{Final Cost Analysis}

$\wp$ Additional cost required to prepare bituminous mix using warm mix technology at $120^{\circ} \mathrm{C}$ and adding $2 \%$ rediset-WMX temperature per Cum $=380-374.017=5.99 \cong 6$ Rs.

$\wp \quad$ Based on the above cost analysis it has been clearly seen that $1.574 \%$ increase in cost of preparing warm bituminous mixes than control mix at hot mix plant.

$\wp$ Obviously there has been $27.27 \%$ reduction in fuel consumption by preparing warm mix than control mix. Overall, preparation of warm bituminous mix required additional cost of 6 Rs. / cum. which is been affordable as the performance is improved than control mix may increase the maintenance period of pavement with BC.

\subsection{Conclusion}

\section{Conclusion And Further Work}

$\wp \quad$ There has been $30^{\circ}$ to $40^{\circ} \mathrm{C}$ reduction in the mixing and compaction temperature of bituminous mixes by adding $2 \%$ additive and satisfied all volumetric requirement for both binders resulting in better performance of bituminous mixes at lower temperature.

$\wp \quad$ The primary advantages of the warm mix asphalt are:

○ Reduce energy consumption

- Reduce emissions

○ Reduce viscosity at working temperature 
$\wp \quad$ The emissions reduction is an important advantage but how beneficial it really is in practice for asphalt producers and buyers is entirely reliant on environmental consciousness and guidelines in each country. Within each country, reduced emissions are especially advantageous for paving projects in heavily inhabited areas and for non-open air paving.

$\wp$ The decreased viscosity of warm mixes is another important benefit. It makes handling of the mix easier and allows effective compaction at lower temperatures where cool down rates are not as rapid.

$\wp \quad$ The overall results are better and positive than the conventional technology used.

$\wp \quad$ This technology also helps to reduce the environment degradation by emission of toxic gases and fume generation.

$\wp \quad$ While doing the laboratory tests the temperature reduction of about $40^{\circ} \mathrm{C}$ has been observed. The results of Marshall Stability test for determination of OT suggests that the most suitable temperature is about $120^{\circ} \mathrm{C}$.

$\wp$ The various volumetric properties are also satisfied at this particular temperature of about $120^{\circ} \mathrm{C}$.

$\wp$ The result of marshall properties for both bituminous mixes with or without using Rediset-WMX satisfy all volumetric properties hence this technology can be adequate for bituminous concrete production.

$\wp$ From the above points it has been verifies that warm mix asphalt production using addition of RedisetWMX is better than the conventional technology used for the preparation of bituminous mix.

\& By using warm mix technology the fuel required for the preparation of mix can be reduced.

$\wp \quad$ In the hot mix plant the fumes has been observed while mixing the aggregate and bitumen mixture together while using warm mix asphalt there is no such fumes has been observed.

\subsection{Further Work}

$\wp$ The present case study can be treated as the base for the further new investigations in similar research fields.

$\wp \quad$ It can be act as a supporting reference work for other studies in warm mix sector.

$\wp$ As per the limitation, the scope is restricted only to the laboratory evaluation of warm mix asphalt technology by the additives. Hence the performance evaluation tests can be carried out in future work.

$\wp \quad$ Performance of this design can be evaluated by conducting various tests on control and warm mix samples.

$\wp$ The performance evaluations tests like Fatigue test, Indirect Tensile Test, Creep test, rutting test, moisture susceptibility, thermal cracking properties, dynamic modulus, high temperature IDT strength, etc. have to be carried out for future investigation.

$\wp \quad$ The economic parameters such as cost effectiveness in maintenance and fuel saving should be evaluated in further studies.

$\wp \quad$ The field implementation of this technology should be carried out in the further work.

$\wp$ This study can also be utilized for other additives of different warm mix asphalt technology.

\section{REFERENCES}

[1]. IS: 2386 (Part 1)-1963: Grain size analysis, Shape test

[2]. IS: 2386 (Part 4)-1963: Impact value test, Abrasion test

[3]. IS: 2386 (Part 3)-1963: Water absorption and Specific Gravity test

[4]. IS: 1203-1978: Penetration test

[5]. IS: 1205-1978: Softening Point test

[6]. IS: 1208-1978: Ductility test

[7]. IS: 1206-1978: Viscosity test

[8]. IS: 1202-1978: Specific Gravity test

[9]. IS: 73-2013: Paving Bitumen- Specification

[10]. MORTH section- 500 clause 509: Design of bituminous concrete

[11]. Khanna S.K. and Justo C.E.G. (2001), "Highway Engineering", Nem Chand and Bros, Rookie, pp315-321.

[12]. Warm mix Asphalt Technologies: An Overview, Journal of Indian Roads Congress, Vol. -2 (2010).

[13]. The asphalt hand book, MS-04

[14]. Dr. Sunil Bose, Mrs. Ambika Behl, Mr. M.N.Nagabhushna, Mr. Gajendra Kumar, Mr. Girish Sharma, Mrs. R. Uma DeviLaboratory Evaluation of Evotherm Additive in Warm Mixes (2011).

[15]. Ramizraja Munshi, "Mechanistic evaluation on warm mix design of bituminous mixes using modified binders" SVNIT Surat.

[16]. Hurley, G.C. and Prowell, B.D. Evaluation of Aspha min for use in Warm Mix Asphalt. Auburn, Alabama: National Center for Asphalt Technology, 2005. NCAT Report 05-04.

[17]. Hurley, G.C., and Prowell, B.D., (2006), "Evaluation of Potential Process for use in Warm Mix Asphalt", Journal of the Association of Asphalt Paving Technologist, Volume 75, pp 41 - 90.

[18]. Prowell, B.D., Hurley, G.C. and Crews, E. Field Performance of Warm Mix Asphalt at the NCAT Test Track. Washington D.C.: Transportation Research Board, 2007.

[19]. Wielinski, J., Hand, A., and Rausch, D. M. (2009). - Laboratory and Field Evaluations of Foamed Warm Mix Asphalt Projects. Transportation Research Board 2009 Annual Meeting, Washington, D.C.

[20]. Prowell, Brian D., Hurley, Graham C and Crews, Everett. Field performance of warm mix asphalt at the NCAT test track. Paper No. 07-2514.

[21]. Dr. Sunil Bose, Mrs. Ambika Behl, Mr. Gajendra Kumar, Mr. Girish Sharma, Mrs. R. Uma Devi- Laboratory Evaluation of SASOBIT Wax-Additive in Warm Mixes (2011) 